Article

\title{
The Role of Travel Motivations and Social Media Use in Consumer Interactive Behaviour: A Uses and Gratifications Perspective
}

\author{
Luciana Chavez $^{1}$ (D) Carla Ruiz ${ }^{1, * D}$, Rafael Curras ${ }^{1}(\mathbb{D})$ and Blanca Hernandez ${ }^{2}(\mathbb{D}$ \\ 1 Department of Marketing, University of Valencia, 46022 Valencia, Spain; luecha@alumni.uv.es (L.C.); \\ rafael.curras-perez@uv.es (R.C.) \\ 2 Department of Marketing, University of Zaragoza, 50005 Zaragoza, Spain; bhernand@unizar.es \\ * Correspondence: carla.ruiz@uv.es; Tel.: +34-96-382-83-12
}

Received: 18 September 2020; Accepted: 20 October 2020; Published: 22 October 2020

check for updates

\begin{abstract}
This paper explores the influence of travel motivations and the gratification provided by social media in consumer stickiness to social media, intention to create user-generated content, and electronic word of mouth (eWOM) review adoption. The study follows a mixed-methods approach. First, a concept mapping study was undertaken to identify the main travel motivations and the gratifications provided by social media when consumers search for information on tourism destinations. A second study using structural equation modelling and SmartPLS 3.2.7 with a sample of 401 heavy users of social media showed the relationships between individual travel motivations and gratifications provided by social media and consumer stickiness, intention to share user-generated content (UGC), and eWOM review adoption.
\end{abstract}

Keywords: uses and gratifications; stickiness; user-generated content; eWOM; social media; travel motivations

\section{Introduction}

Over the last decade, the emergence of user-generated content (UGC) on social media has revolutionised tourists' perceptions, attitudes, and even behaviours with regard to destinations, hotels, and restaurants [1,2]. Travellers increasingly visit social media to search for travel-related information, including online reviews, because they believe comments and experiences posted by other consumers help them make better destination choices [3]. This trend is closely related to some tourism characteristics (e.g., intangibility and experience). UGC improves tourists' decision-making and increases their information about destinations, generating social capital [4,5].

Motivations have long been a critical topic in tourism and consumer behaviour [6,7] as they provoke and guide individual behaviours [8]. The extant tourism literature indicates that travel motivations underlie travellers' decision-making processes and are key triggers of purchasing behaviours [6,9-11]. Hence, a research question arises about the understanding of the role of travel motivations in consumer behaviour on social media when they search for travel-related information.

Tourists' travel motivations and the uses and gratifications theory (UGT) have been jointly used in the conceptual framework in this analysis. UGT helps to explain the functions of the medium for the individual [12], and furthers the understanding of why individuals use social media to satisfy their needs and, therefore, what main gratifications they obtain from tourism-based social media. The general idea is that individuals seek gratifications of their needs from social media content. The understanding of why, and how, specific activities (including those related to posting and sharing travel information) are undertaken on social media is, as yet, quite limited [13-15]. More specifically, social media support a broad range of activities, and its use and the gratifications it provides vary considerably 
among users [14]. Understanding the gratifications individuals seek, and obtain, when searching for information about tourism destinations provides a richer picture of their interactive behaviour.

Stickiness is the ability of websites to attract and retain customers so that they will buy goods/services, or view more advertisements [16]. This ability has been recognised as one of the keys to profitability. It is in the best interests of online travel communities to retain visitors for as long as they can, since the probability of them booking a trip or viewing an advertisement increases with the time they stay on the site [17]. As a result of repeat traffic and increased time spent on sites, customers become stickier to social media. Despite all the efforts that they put into creating stickiness, what makes customers stick around is still vague to social media managers. Given the increasing competition in the hospitality industry, it is important for managers to identify the drivers of the individual's intention to post and adopt the advice of electronic word of mouth (eWOM) reviews posted on social media, as this has considerable influence on his or her information processing and decision-making [18-20].

This study explores the influence of travel motivations and the gratifications provided by social media in customer interactive behaviour. The study integrates individual and social motivations to travel with the gratifications obtained through using social media for tourism purposes. It is expected that the study will enrich previous research into uses and gratifications and UGC. The work is divided into two parts. The first part, the theoretical part, presents the literature review, the working hypotheses, and the methodology. The second follows a mixed-methods' approach. First, a concept mapping study is undertaken to identify the uses and gratifications of social media and travel motivations when consumers search for information on tourism destinations. A second study, using structural equation modelling with SmartPLS 3.2.7, with a sample of 401 heavy users of social media, examines the impact of relationships between individual travel motivations and the gratifications provided by social media on: consumer stickiness, intention to share UGC, and eWOM review adoption.

\section{Conceptual Background}

\subsection{Uses and Gratifications Theory and Social Media}

The uses and gratifications theory (UGT) identifies why people use certain media [21]. Scholars have utilized the theory to understand the different gratifications that individuals seek from the use of social media to perform specific activities [22]. UGT posits that audience members are active and goal-oriented consumers of media who select media and messages to satisfy their needs. They are aware of their interests and motives and have certain expectations that lead them to choose certain media and types of gratification [23].

Some authors negatively criticise UGT. Reference [24] showed the conceptual ambiguities and inconsistencies of the UGT, and Reference [25] doubted its definition and measurement of gratification. Reference [26] showed that the UGT provides lists only of reasons why audiences employ certain media. Nevertheless, many researchers consider the UGT as one of the most influential theories in the field of communication research [27]. The UGT is especially well suited to examine the use of social media because of its high levels of involvement [27], bonding social capital [28], participant interactivity [29], and positive vs. negative brand communication [30]. Through social media tourism destinations can provide value and/or gratification for tourists by optimising the content they produce. Recent research has shown that the gratifications provided by social media platforms have a significant influence on continuance intentions [31]. The UGT can explain, not only why consumers use social media, but also why they are willing to stay longer when searching for, or sharing, tourism information (social media stickiness). The theory also suggests that gratifications influence users' attitudes, and that those attitudes guide users' actual usage [32], and travel behaviours [33].

An increasing number of researchers have adopted UGT to explain the gratifications obtained from social media. In accordance with previous research, we acknowledge the need for a comprehensive and systematic literature review that provides a full understanding of the current knowledge of the 
topic as applied to the tourism field. Table 1 in Annex 1 presents the main findings of recent studies into UGT and tourism-based social media.

Table 1. Social media and tourism: recent uses and gratifications theory (UGT) studies.

\begin{tabular}{|c|c|c|c|c|}
\hline Context & Author & Gratifications & Sample & Main Findings \\
\hline $\begin{array}{l}\text { Use of mobile } \\
\text { social media for } \\
\text { travelling }\end{array}$ & [33] & $\begin{array}{l}\text { Informativeness } \\
\text { Social interactivity } \\
\text { Playfulness }\end{array}$ & $\begin{array}{l}500 \text { senior Korean } \\
\text { travellers, mobile } \\
\text { SNS users } \\
\text { Online survey }\end{array}$ & $\begin{array}{l}\text { Informativeness, social } \\
\text { interactivity and } \\
\text { playfulness influence } \\
\text { consumers' attachment to } \\
\text { mobile social media for } \\
\text { travelling. }\end{array}$ \\
\hline $\begin{array}{l}\text { Hotel Facebook } \\
\text { fanpages }\end{array}$ & [34] & $\begin{array}{l}\text { Information } \\
\text { Convenience } \\
\text { Self-expression } \\
\text { Social interaction } \\
\text { Entertainment }\end{array}$ & $\begin{array}{l}357 \text { users of hotel } \\
\text { Facebook fanpages. } \\
\text { Online survey }\end{array}$ & $\begin{array}{l}\text { Information, convenience, } \\
\text { and self-expression drive } \\
\text { user satisfaction with the } \\
\text { hotel's Facebook page }\end{array}$ \\
\hline $\begin{array}{l}\text { Use of social media } \\
\text { for travelling }\end{array}$ & [35] & $\begin{array}{l}\text { Information } \\
\text { seeking } \\
\text { Entertainment } \\
\text { Relationship } \\
\text { maintenance }\end{array}$ & $\begin{array}{l}450 \text { Korean } \\
\text { travellers, social } \\
\text { media users. } \\
\text { Online survey }\end{array}$ & $\begin{array}{l}\text { Information seeking, } \\
\text { entertainment, and } \\
\text { relationship maintenance } \\
\text { motives trigger travellers' } \\
\text { propensity to display } \\
\text { higher social media } \\
\text { continuance usage and } \\
\text { information sharing } \\
\text { intentions. }\end{array}$ \\
\hline $\begin{array}{l}\text { Tourism-related } \\
\text { sponsored } \\
\text { advertisements on } \\
\text { Facebook }\end{array}$ & [36] & $\begin{array}{l}\text { Altruism } \\
\text { Entertainment } \\
\text { Socialising } \\
\text { Information } \\
\text { seeking } \\
\text { Information } \\
\text { sharing } \\
\text { Self-expression }\end{array}$ & $\begin{array}{l}487 \text { UK Facebook } \\
\text { users } \\
\text { Online and } \\
\text { face-to-face survey }\end{array}$ & $\begin{array}{l}\text { Altruism, entertainment, } \\
\text { socialising, and } \\
\text { information seeking are } \\
\text { positive drivers of } \\
\text { intention to share } \\
\text { tourism-related sponsored } \\
\text { advertisements on } \\
\text { Facebook }\end{array}$ \\
\hline $\begin{array}{l}\text { Use of social media } \\
\text { for travelling }\end{array}$ & [37] & $\begin{array}{l}\text { Information-seeking } \\
\text { Entertainment } \\
\text { Relationship } \\
\text { maintenance }\end{array}$ & $\begin{array}{l}475 \text { Thai tourists } \\
\text { Online survey }\end{array}$ & $\begin{array}{l}\text { Information-seeking, } \\
\text { entertainment relationship } \\
\text { maintenance and Internet } \\
\text { self-efficacy positively } \\
\text { influence the intention to } \\
\text { use SNSs for trips. }\end{array}$ \\
\hline $\begin{array}{l}\text { Food-related } \\
\text { content on social } \\
\text { media }\end{array}$ & [38] & $\begin{array}{l}\text { Content } \\
\text { information } \\
\text { Content } \\
\text { entertainment } \\
\text { Social interaction } \\
\text { Self-expression }\end{array}$ & $\begin{array}{l}707 \text { Chinese food } \\
\text { tourists } \\
\text { Online survey }\end{array}$ & $\begin{array}{l}\text { Positive associations } \\
\text { between content } \\
\text { entertainment and } \\
\text { Informational Social } \\
\text { Impact (ISI), and between } \\
\text { self-expression and } \\
\text { Normative Social Impact } \\
\text { (NSI). Content information } \\
\text { and social interaction had } \\
\text { a positive relationship } \\
\text { with both NSI and ISI. }\end{array}$ \\
\hline
\end{tabular}

Source: own design.

Previous studies have identified social enhancement, entertainment and self-expression as some of the key gratifications obtained from social media use (see Table 1). Drawing on UGT and concept mapping research, the present study anticipates that consumers will use social media for tourism purposes to gratify their needs for entertainment, knowledge sharing, and social enhancement. 
The entertainment construct of UGT refers to the extent to which social media content gives hedonic value to consumers [39]. The UGT proposes that consumers use social media to find fun, escapism, and spontaneity [30,40]. This hedonic value increases when virtual environments stimulate the consumer's imagination. The travel-based content on social media today offers consumers high entertainment value by allowing them to share photographs and comments. The informational construct of UGT (information sharing) represents the extent to which social media content allows users to create and share helpful information [30]. Tourists find social media comfortable places to reveal their feelings about trips or destinations, share views and experiences, and inform their family and friends about their tourism experiences. The social construct of UGT (social enhancement) refers to the extent to which social media content helps users to express their personalities, gain peer-support, and develop a sense of belonging to a group of friends, family, and society, substituting real-life partnerships [41]. The expression of identity or status positively reinforces individuals' attitudes towards use of the medium or service [42,43].

\subsection{Effects of the Gratifications Provided by Social Media Use on Consumer Interactive Behaviour}

In this research social media stickiness is measured through the time spent by consumers on social media platforms looking for information about tourism destinations. Media stickiness increases in line with the individual's perceived value of social media content [44]. Recent research has highlighted that gratifications are key drivers of social media use [33,35,37]. Reference [45] found that entertainment, expressive information sharing, and social interaction gratifications predict online travel communities' ability to retain users. Therefore, we have the following hypothesis:

Hypothesis 1 (H1). The gratifications obtained from social media use for tourism purposes positively influence consumers' stickiness towards social media.

The gratifications provided by social media use have been associated to UGC sharing behaviour. Entertainment gratification has been associated with link sharing [46], news sharing [47], online advertisement sharing [48], photo sharing [15], and tourism related sponsored-ad sharing [36]. Expressive information sharing refers to the need to share information about travel experiences with others. Recent studies in online contexts have validated the positive effect of knowledge sharing gratification $[15,46,49-51]$ on UGC sharing in non-commercial environments. Social gratifications represent the individual's perception of how his/her actions are viewed by others. In self-enhancement gratification, individuals feel the need to share personal experiences to be perceived as "cool" by other users. Social media enable travellers to share photographs and manage their desired self-images and keep abreast of the latest tourism destination trends. Thus, consumers see social media as symbols of social identity, which help them to reinforce their sense of belonging to a specific group of travellers. The possibility of enhancing one's reputation is an important driver for sharing UGC [52,53]. Individuals who desire social enhancement perceive more utility in engaging in behaviours that increase their feelings of personal worth and lead to higher social status in the travel community [40].

The gratifications obtained through social media condition consumers' evaluations of tourism experiences, which can be reflected in their desire to transmit information to other consumers and in the comments they post [54]. Reference [55] found that UGC exchanges about airline services had a positive effect on the individual's willingness to engage in positive eWOM. Reference [56] showed a positive association between the perceived benefits of social media use and continuance intentions to create UGC on social media. It is proposed that, when consumers use social media for tourism purposes, they obtain entertainment, expressive information sharing, and social gratifications, which in turn, positively influence their continuance intentions to create UGC on social media about their tourism experiences. 
Hypothesis 2 (H2). Gratifications obtained from social media use for tourism purposes positively influence consumers' continuance intention to create user-generated content.

UGC has higher influence than firm-generated content on consumer decision-making [57]. Ha et al. [32] posited that gratifications obtained by social media use positively influence consumers' attitudes towards social media. Reference [58] showed that eWOM on social media is an important driver of consumer choice of tourism destinations. Reference [20] demonstrated that the informative content and pleasure elicited by UGC on social media has a positive influence on consumers' willingness to follow advice provided on social media about visiting a restaurant. Therefore, we posit that the gratifications provided by social media positively influence eWOM review adoption.

Hypothesis 3 (H3). The gratifications obtained from social media use for tourism purposes positively influence consumers' eWOM review adoption.

\subsection{Travel Motivations and Consumer Interactive Behaviour}

Reference [59]'s study into travel motivations asked, "what makes tourists travel?" Adapting this question (see Reference [59]), the present study is designed to answer the question, "what makes social media users travel to a tourism destination for leisure?". The push and pull framework has been most commonly used to explain travel motivations $[60,61]$. People travel because they are pushed by internal forces (e.g., desire for escape, rest, relaxation, prestige, adventure, social interaction), and, at the same time, pulled by external forces such as interest in a destination's attributes [62]. Reference [63] argued that two motivational forces influence tourists: (a) the desire to leave the everyday environment behind and (b) the desire to obtain psychological rewards through travel in an environment that contrasts with the home environment.

This study investigates the impact of four push travel motivations (leisure, relaxation, learning/discover, and social bonding) for visiting a tourism destination on consumers' interactive behaviour on social media. Leisure motivation, which is related to adventure seeking and the wish to enjoy exciting experiences, influences destination choice $[64,65]$. Relaxation motivation encompasses the need for escape. Escape-driven travellers are eager to enjoy physical and social breaks from their everyday living and working environments [66]. The learning/discover dimension relates to individuals' aspirations to find new/different experiences and knowledge, and alleviate boredom [67]. Learning and discovering something new is similar to enjoying novel vacation experiences $[66,68]$. Social bonding is the process of the development/facilitation of relationships with others [36]. Individuals, however, can also develop relationships among groups on social media, focused on sharing experiences, for example, about leisure, travel, etc. [69] pointed out that travel motivations predispose people to participate in tourist activities. Reference [70] described tourism motivations as individuals' activated psychological states that direct them towards the fulfilment of tourism needs. When travellers' needs are stimulated, they form travel motivations, which drive them to take actions to meet their tourism needs and decrease tension [10].

In travellers' decision-making, individuals choose, encode, process, and remember most information provided by social media in ways consistent with their travel motivations. Social media allow travellers to follow topics of interest and provide the chance to receive constant updates from other users. Travel motivation is increased by social media use, and an emotional connection and expectations are created before a destination is experienced [71]. Reference [72] demonstrated that push travel motivations can predict the type of content that different traveller segments prefer to view on social media. Reference [73] argued that the motivation to obtain updated information drives intensity of social media use. Therefore, we propose that the stronger are the tourist's travel motivations, the greater will be his/her stickiness to the social media that can help him/her fulfil his/her needs in ways consistent with his/her travel motivations. 
Hypothesis 4a (H4a). Leisure travel motivation positively influences consumer stickiness to social media.

Hypothesis $4 \mathbf{b}(\mathbf{H} 4 \mathbf{b})$. Relaxation travel motivation positively influences consumer stickiness to social media.

Hypothesis $4 \mathbf{c}(\mathbf{H} 4 \mathrm{c})$. Learning/discover travel motivation positively influences consumer stickiness to social media.

Hypothesis $4 \mathbf{d} \mathbf{( H 4 d ) . ~ S o c i a l - b o n d i n g ~ t r a v e l ~ m o t i v a t i o n ~ p o s i t i v e l y ~ i n f l u e n c e s ~ c o n s u m e r ~ s t i c k i n e s s ~ t o ~}$ social media.

Word of mouth behaviour in the tourism context is an integrative process initiated by a tourism experience [74], and subsequently spread on social media [75]. During their travels, tourists tend to express their feelings on social media and to co-create value with tourism providers and other consumers. Reference [76] evidenced the positive impact of social-bonding travel motivations and relaxation and adventure on tourists who took boat trips intention to recommend these tours. Reference [77] identified travel motivations related to social bonding (e.g., travelling with family/friends to boost relationships), seeking new experiences, relaxation, and leisure (e.g., enjoying a city's cuisine, sightseeing), that significantly influenced visitor intention to recommend cultural attractions. Reference [78] posited that individual travel motivations influence photo-sharing on social media. Reference [79] suggested that the enjoyment motivation affects travel-experience sharing on social media. Therefore, we posit that travel motivations influence the consumer's intention to create user-generated content on social media.

Hypothesis 5a (H5a). Leisure travel motivation positively influences continuance intention to create user-generated content.

Hypothesis $\mathbf{5 b}(\mathbf{H} 5 \mathbf{b})$. Relaxation travel motivation positively influences continuance intention to create user-generated content.

Hypothesis $\mathbf{5 c} \mathbf{( H 5 c ) . ~ L e a r n i n g / d i s c o v e r ~ t r a v e l ~ m o t i v a t i o n ~ p o s i t i v e l y ~ i n f l u e n c e s ~ c o n t i n u a n c e ~ i n t e n t i o n ~ t o ~ c r e a t e ~}$ user-generated content.

Hypothesis $\mathbf{5 d} \mathbf{( H 5 d ) . ~ S o c i a l - b o n d i n g ~ t r a v e l ~ m o t i v a t i o n ~ p o s i t i v e l y ~ i n f l u e n c e s ~ c o n t i n u a n c e ~ i n t e n t i o n ~ t o ~ c r e a t e ~}$ user-generated content.

Motivation is one of the core theoretical issues of consumer behaviour in tourism [60] because it helps to explain why people revisit certain destinations [76]. However, while travel motivations have emerged as an influential factor that affect tourists' post-purchase behaviours, their impact is not homogenous, given the diversity of tourism activities and destinations [76,80-84]. For example, tourists visiting cultural destinations are driven by knowledge motivations [80]; consumers' revisit intentions towards nature-based destinations are motivated by pursuing new types of travel [81]; and tourists travelling to leisure destinations are mainly motivated by escaping from routine [82]. Reference [76] found three types of travel motivations: social, utilitarian, and hedonic motivations influenced boat tour participants' intention to retake the tours. Reference [83] found that, among other motivations, adventure and relaxation increased travellers' intentions to undertake space trips. [84] found that leisure and social-bonding motivations (visiting family and friends) had a significant influence on the visiting intentions towards a tourism destination among repeat travellers. We conceptualise eWOM adoption as the intention to follow advice to visit a tourism destination based on the comments, recommendations, and suggestions posted on social media by other travellers. The present study extends previous works by focusing on the influence of travel motivations on consumer interactive 
behaviour. Therefore, we posit that travel motivations positively influence the consumer's adoption of eWOM posted on social media.

Hypothesis 6a (H6a). Leisure travel motivation positively influences eWOM review adoption.

Hypothesis $\mathbf{6 b} \mathbf{( H 6 b ) . ~ R e l a x a t i o n ~ t r a v e l ~ m o t i v a t i o n ~ p o s i t i v e l y ~ i n f l u e n c e s ~ e W O M ~ r e v i e w ~ a d o p t i o n . ~}$

Hypothesis 6c (H6c). Learning/discover travel motivation positively influences eWOM review adoption.

Hypothesis 6d (H6d). Social-bonding travel motivation positively influences eWOM review adoption.

\subsection{Stickiness, User-Generated Content, and eWOM Review Adoption}

In this research, stickiness to social media is defined as the user's willingness to return to and prolong his or her visits to social media for tourism purposes [85]. Stickiness to social media can be shown in the form of revisits. Reference [86] showed that more loyal consumers visited and used particular websites more frequently, increasing stickiness to those sites. In the context of company social networks, Reference [87] argued that stickiness influenced WOM. Recent research [74] has shown that extensive use of social media reinforces tourists' perceptions and evaluations of aspects of their visits, which allows their social media contacts to benefit from their sharing of their travel experiences and recommendations about destinations [88]. Therefore, we get the following hypothesis:

Hypothesis 7 (H7). Stickiness to social media positively influences continuance intention to create user-generated content.

Customers' stickiness to social media is formed when they adopt a positive attitude towards the contents of the social media and develop loyal behaviour, such as attachment [89]. Reference [19] found that attitude towards the advice obtained in an online travel community had a positive influence on traveller intention to follow that advice. Taking these points into account, we adapt this relationship to our analysis context and propose that stickiness to travel-related content on social media will positively influence the traveller's adoption of eWOM.

Hypothesis 8 (H8). Stickiness to social media positively influences eWOM review adoption.

Figure 1 shows the research model. 


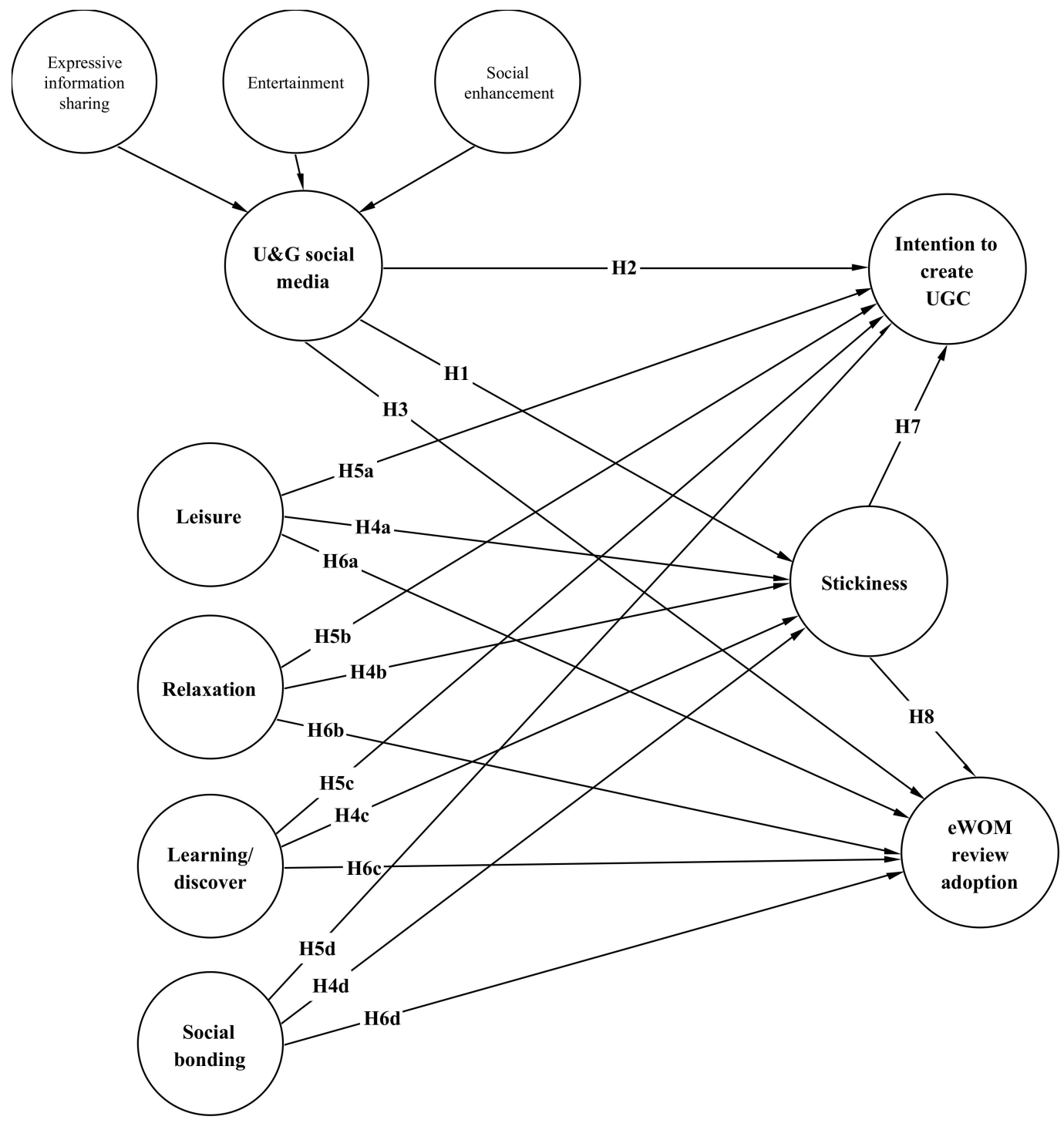

Figure 1. Research model.

\section{Methods}

This study adopts a mixed-method research approach [90]. Mixed methods offer a better understanding of research problems by triangulating sets of results and, thus, enhancing the validity of inferences. Accordingly, a two-step study was implemented. First, a qualitative analysis, employing a concept mapping design [91], using heavy users of social media for tourism-related purposes, was carried out. Second, a quantitative analysis using PLS was conducted, with 401 heavy users of social media, to estimate the conceptual model.

\subsection{Study 1: Concept Mapping}

The main goal of study 1 was to identify and refine scales to measure the model's core constructs, the gratifications provided by social media and travel motivations. Gratifications are a complex, multidimensional, and formative construct, and the previous literature provides no standardised scales. We decided to develop concept mapping [91], a mixed method that generates concept maps, using multidimensional scaling (i.e., MDS), and cluster analysis derived from focus group results. This technique is employed in scale development studies [92] to confirm the dimensionality of complex constructs and identify key items. 
The focus group comprised of 12 tourist users of social media services [91]. They were asked to create a list of their travel motivations and explain why, when, and how they used social media platforms for travel purposes. The participants then shared their opinions with the group. Using MDS and cluster analysis we obtained the concept mapping for the gratifications and travel motivations of the whole group. Thereafter, a consensus was reached as to the grouping of the various dimensions, and any ambiguities were eliminated. In sum, the results of study 1 were used to refine the dimensionalisation and items for the gratifications and travel motivations variables.

\subsection{Study 2: Online Survey}

\subsubsection{Design and Sample}

To verify the proposed hypotheses and estimate the conceptual model, an empirical study was carried out with data gathered by an online survey, using a structured questionnaire. The questionnaire was initially revised by two experts on tourism, using a small sub-sample ( $n=18)$ of the study population, consumers over 18 years of age that use social media for tourism purposes. This revision ensured that the questionnaire gathered all the relevant information, addressed misinterpretations and misunderstandings in some of the questions, and allowed us to improve the adaptation of some of the scales to the study context. This pre-test ensured the content validity of the scales.

The study population claimed to frequently ( $92 \%$ at least once a month) use social media as a source of touristic information. The study was conducted in Spain. The data were collected between January and March 2019. The sample was selected on the basis of age and gender quotas to ensure it largely reflected the socio-demographic profile of Spanish Internet users, according to [93]. We used the convenience sampling procedure; the questionnaire was distributed through social network profiles and ad hoc email lists among tourists who had used social media as a source of tourist information in the previous year, e.g., through the non-travel-specific social networks Facebook, Instagram, and YouTube, and the travel-specific sites Booking.com and TripAdvisor.com, or personal travel blogs.

A total of 401 individuals returned valid responses. Table 2 shows the sociodemographic profiles and behavioural characteristics of the sample. The sample had a balanced ratio of men (56\%) and women $(44 \%)$, most being under $35(54 \%)$. More than half $(58 \%)$ of the sample had university degrees and were employed $(60 \%)$. Some $64 \%$ of the sample used social media platforms daily to post, share, or like information in the previous three months, and $75 \%$ have read information on social media daily in the previous three months. Finally, $89 \%$ of the sample had posted tourism-related information on social media in the previous year.

Table 2. Characteristics of the sample.

\begin{tabular}{ccc}
\hline Characteristic & & \% (n = 401) \\
\hline \multirow{2}{*}{ Gender } & Men & 56 \\
& Women & 44 \\
\hline \multirow{2}{*}{ Age } & $18-25$ & 20 \\
& $26-35$ & 34 \\
& $36-45$ & 26 \\
& $46-55$ & 13 \\
\multirow{2}{*}{ Educational level } & $>55$ & 7 \\
& Secondary & 9 \\
& Undergraduate & 33 \\
\hline
\end{tabular}


Table 2. Cont.

\begin{tabular}{ccc}
\hline Characteristic & & $\% \mathbf{~ ( n ~ = ~ 4 0 1 ) ~}$ \\
\hline & Student & 24 \\
Occupation & Self-employed & 16 \\
& Employed & 44 \\
& Unemployed & 5 \\
& Retired & 5 \\
How often have you interacted with & Others & 6 \\
social media for tourism purposes in the & Daily & 64 \\
last three months? & Once a week & 16 \\
& Twice a month & 12 \\
How often have you read posts with & Less than once a month & 8 \\
travel-related information on social & Daily & 75 \\
media in the last three months? & Once a week & 15 \\
& Twice a month & 7 \\
When was the last time you posted & Less than once a month & 3 \\
travel-related information on & $<1$ year ago & 89 \\
social media? & $>1$ year ago & 9 \\
\hline
\end{tabular}

\subsubsection{Measures}

Gratifications provided by social media use were measured as second order constructs formatively related to their dimensions; these dimensions are reflectively related to their indicators. This theoretical structure was estimated by using the "repeated indicator approach" [94] of the partial least squares (PLS) algorithm. Although the previous literature contains negative criticisms about the functionality of the PLS-SEM algorithm in business and management research [95,96], the approach has also been supported in recent studies $[97,98]$ as a structural modelling technique that allows the incorporation of second-order constructs of a formative nature (as is our case); this avoids model identification problems [99-101]. The parameters were estimated by using Smart-PLS 3.0 [102]; 5000 samples were bootstrapped to calculate the significance of the parameters.

The scales, all seven-point Likert-type, used in the questionnaire to measure the constructs were taken from previous studies in the academic literature. Table 3 shows the detailed scale items and the main statistics of each variable (mean and standard deviations).

Uses and gratifications was estimated as a second-order factor formatively configured, based on the results of the concept mapping technique (study 1), and the scales of References [103] and [104], through three dimensions: (i) expressive information sharing - 3 scale items; (ii) entertainment-4 items; and (iii) social enhancement-3 items. Travel motivations were measured on a scale developed by [61], and based on the results of study 1 . We identified four travel motivations: (i) leisure- 3 items; (ii) relaxation-3 items; (iii) learning/discover -4 items; and (iv) social bonding - 3 items. Stickiness was measured on a 3-item scale developed by [105], adapted to the context of this research. Continuance intention to create user-generated content was measured by adapting Reference [106]'s 4-item scale; eWOM review adoption was measured by using 4 items adapted from Reference [107]'s scale. 
Table 3. Measurement of the variables.

\begin{tabular}{|c|c|c|c|c|}
\hline Source & Variable & Item & Mean & SD \\
\hline \multirow{10}{*}{$\begin{array}{l}\text { Uses and } \\
\text { Gratifications } \\
\text { of social } \\
\text { media }\end{array}$} & \multirow{3}{*}{$\begin{array}{l}\text { Expressive } \\
\text { information } \\
\text { sharing }\end{array}$} & To provide information. & 4.67 & 1.95 \\
\hline & & $\begin{array}{l}\text { To present information } \\
\text { about my special interests. }\end{array}$ & 4.60 & 2.02 \\
\hline & & $\begin{array}{l}\text { To share information that } \\
\text { may be of use or interest } \\
\text { to others. }\end{array}$ & 5.23 & 1.77 \\
\hline & \multirow{4}{*}{ Entertainment } & Because I like it. & 5.26 & 1.79 \\
\hline & & $\begin{array}{l}\text { Because I just like to play } \\
\text { around on social media. }\end{array}$ & 4.52 & 1.98 \\
\hline & & $\begin{array}{l}\text { When I have nothing better } \\
\text { to do. }\end{array}$ & 3.86 & 2.00 \\
\hline & & $\begin{array}{l}\text { Because it passes the time, } \\
\text { particularly when I } \\
\text { am bored. }\end{array}$ & 4.64 & 1.94 \\
\hline & \multirow{3}{*}{$\begin{array}{c}\text { Social } \\
\text { enhancement }\end{array}$} & To attract attention. & 2.64 & 1.79 \\
\hline & & $\begin{array}{l}\text { Because my posts make me } \\
\text { seem cool to my peers. }\end{array}$ & 2.45 & 1.74 \\
\hline & & $\begin{array}{l}\text { Because I like when people } \\
\text { read things about me. }\end{array}$ & 2.92 & 1.83 \\
\hline \multirow{3}{*}{$\begin{array}{c}\text { Leisure } \\
\text { travel } \\
\text { motivation }\end{array}$} & LEI1 & To seek adventure & 5.19 & 1.67 \\
\hline & LEI2 & To seek diversion and entertainment & 5.24 & 1.63 \\
\hline & LEI3 & To live exciting experiences & 5.28 & 1.70 \\
\hline \multirow{3}{*}{$\begin{array}{l}\text { Relaxation } \\
\text { travel } \\
\text { motivation }\end{array}$} & REL1 & To rest/to relax & 4.99 & 1.86 \\
\hline & REL2 & To alleviate stress & 4.90 & 1.98 \\
\hline & REL3 & To escape & 5.13 & 1.95 \\
\hline \multirow{4}{*}{$\begin{array}{l}\text { Learning/ } \\
\text { discover } \\
\text { travel } \\
\text { motivation }\end{array}$} & LEA1 & To discover new places & 5.74 & 1.57 \\
\hline & LEA2 & To explore historical and cultural heritage & 5.62 & 1.56 \\
\hline & LEA3 & $\begin{array}{c}\text { To learn about other cultures and ways } \\
\text { of life }\end{array}$ & 5.70 & 1.53 \\
\hline & LEA4 & To enrich myself intellectually & 5.51 & 1.67 \\
\hline \multirow{3}{*}{$\begin{array}{l}\text { Social-bonding } \\
\text { travel } \\
\text { motivation }\end{array}$} & BON1 & To meet new people & 4.97 & 1.94 \\
\hline & BON2 & $\begin{array}{l}\text { To integrate myself into the life and } \\
\text { activities of local people }\end{array}$ & 4.61 & 1.98 \\
\hline & BON3 & To communicate with my friends & 4.94 & 1.91 \\
\hline \multirow{3}{*}{ Stickiness } & STICK1 & $\begin{array}{l}\text { I could spend a long time on social media } \\
\text { sites reviewing travel-related information. }\end{array}$ & 4.25 & 1.84 \\
\hline & STICK2 & $\begin{array}{l}\text { media sites to review travel-related } \\
\text { information every time I am online }\end{array}$ & 4.35 & 1.87 \\
\hline & STICK3 & $\begin{array}{l}\text { I would like to review travel-related } \\
\text { information on social media sites more often }\end{array}$ & 4.19 & 1.85 \\
\hline \multirow{4}{*}{$\begin{array}{l}\text { Continuance } \\
\text { intention to } \\
\text { create UGC }\end{array}$} & UGC1 & $\begin{array}{l}\text { I intend to create more travel-related } \\
\text { content and share it with others on social } \\
\text { media sites if possible }\end{array}$ & 3.63 & 1.98 \\
\hline & UGC2 & $\begin{array}{l}\text { I intend to post more travel-related } \\
\text { information on social media sites }\end{array}$ & 3.52 & 1.97 \\
\hline & UGC3 & $\begin{array}{l}\text { I intend to spend more time viewing } \\
\text { travel-related posts on social media sites }\end{array}$ & 3.80 & 1.93 \\
\hline & UGC4 & $\begin{array}{c}\text { I intend to participate more on social media } \\
\text { sites in the future, especially on } \\
\text { travel-related matters }\end{array}$ & 3.79 & 1.93 \\
\hline
\end{tabular}


Table 3. Cont.

\begin{tabular}{ccccc}
\hline Source & Variable & Item & Mean & SD \\
\hline eWOM1 & $\begin{array}{c}\text { Information from online reviews } \\
\text { contributed to my knowledge of the } \\
\text { tourism destination } \\
\begin{array}{c}\text { eWOM } \\
\text { review } \\
\text { adoption }\end{array}\end{array}$ & $\begin{array}{c}\text { Information from online reviews helped me } \\
\text { to make the decision to visit the tourism } \\
\text { destination }\end{array}$ & 5.14 & 1.63 \\
& eWOM3 & $\begin{array}{c}\text { Information from online reviews enhanced } \\
\text { my effectiveness in making the decision to } \\
\text { visit the tourism destination }\end{array}$ & 5.16 & 1.64 \\
& eWOM4 & $\begin{array}{c}\text { Information from online reviews motivated } \\
\text { me to visit the tourism destination }\end{array}$ & 5.08 & 1.64 \\
\hline & UGC = user-generated content. & &
\end{tabular}

\subsubsection{Psychometric Properties of the Measurement Instrument}

The indicators demonstrated the high internal consistency of the constructs (see Table 4). In all cases, Cronbach's alpha exceeded Reference [108]'s recommendation of 0.70. Composite reliability represents the shared variance among a set of observed variables measuring an underlying construct [109]. Generally, a composite reliability of at least 0.60 is considered desirable [110]. This requirement was met for all factors. The average variance extracted (AVE) was also calculated for all constructs; the AVEs were greater than 0.50 [108]. As evidence of convergent validity, the results indicated that all items were significantly $(p<0.01)$ related to their hypothesised factors, and the standardised loadings were at least 0.60 [109]. Table 4 shows the individual loads for each item and the construct reliability.

Table 4. Confirmatory Factor Analysis results and measurement model psychometric properties.

\begin{tabular}{|c|c|c|c|c|c|c|c|c|}
\hline \multirow{2}{*}{\multicolumn{2}{|c|}{ Construct }} & \multirow[b]{2}{*}{ Item } & \multicolumn{3}{|c|}{ Convergent Validity } & \multicolumn{3}{|c|}{ Reliability } \\
\hline & & & Loads & $t$-Value & $\begin{array}{l}\text { Loading } \\
\text { Average }\end{array}$ & $\begin{array}{c}\text { Cronbach's } \\
\alpha\end{array}$ & $\begin{array}{l}\text { Composite } \\
\text { Reliability }\end{array}$ & AVE \\
\hline \multirow{3}{*}{\multicolumn{2}{|c|}{ Stickiness }} & STICK1 & 0.90 & 74.30 & & & & \\
\hline & & STICK2 & 0.92 & 89.76 & 0.90 & 0.89 & 0.93 & 0.82 \\
\hline & & STICK3 & 0.89 & 60.23 & & & & \\
\hline \multirow{4}{*}{\multicolumn{2}{|c|}{$\begin{array}{l}\text { Continuance intention } \\
\text { to create UGC }\end{array}$}} & UGC1 & 0.90 & 79.29 & \multirow{4}{*}{0.89} & \multirow{4}{*}{0.91} & \multirow{4}{*}{0.94} & \multirow{4}{*}{0.79} \\
\hline & & UGC 2 & 0.92 & 85.96 & & & & \\
\hline & & UGC 3 & 0.86 & 45.24 & & & & \\
\hline & & UGC 4 & 0.86 & 50.57 & & & & \\
\hline \multirow{4}{*}{\multicolumn{2}{|c|}{ eWOM review adoption }} & eWOM1 & 0.89 & 52.29 & \multirow{4}{*}{0.92} & \multirow{4}{*}{0.94} & \multirow{4}{*}{0.96} & \multirow{4}{*}{0.85} \\
\hline & & eWOM2 & 0.93 & 92.14 & & & & \\
\hline & & eWOM3 & 0.94 & 96.55 & & & & \\
\hline & & eWOM4 & 0.94 & 74.76 & & & & \\
\hline \multirow{10}{*}{$\begin{array}{l}\text { Social media } \\
\text { gratifications }\end{array}$} & \multirow{3}{*}{$\begin{array}{l}\text { Information } \\
\text { sharing }\end{array}$} & EIS1 & 0.92 & 90.18 & \multirow{3}{*}{0.90} & \multirow{3}{*}{0.88} & \multirow{3}{*}{0.93} & \multirow{3}{*}{0.81} \\
\hline & & EIS2 & 0.91 & 84.00 & & & & \\
\hline & & EIS3 & 0.86 & 41.39 & & & & \\
\hline & \multirow{4}{*}{ Entertainment } & ENT1 & 0.81 & 40.49 & \multirow{4}{*}{0.83} & \multirow{4}{*}{0.85} & \multirow{4}{*}{090} & \multirow{4}{*}{0.69} \\
\hline & & ENT2 & 0.87 & 48.48 & & & & \\
\hline & & ENT3 & 0.84 & 51.24 & & & & \\
\hline & & ENT4 & 0.81 & 33.51 & & & & \\
\hline & \multirow{3}{*}{ Social-enhancement } & SOC1 & 0.89 & 59.89 & \multirow{3}{*}{0.89} & \multirow{3}{*}{0.87} & \multirow{3}{*}{0.92} & \multirow{3}{*}{0.80} \\
\hline & & SOC2 & 0.89 & 59.73 & & & & \\
\hline & & SOC3 & 0.90 & 64.23 & & & & \\
\hline
\end{tabular}


Table 4. Cont.

\begin{tabular}{|c|c|c|c|c|c|c|c|}
\hline \multirow[b]{2}{*}{ Construct } & \multirow[b]{2}{*}{ Item } & \multicolumn{3}{|c|}{ Convergent Validity } & \multicolumn{3}{|c|}{ Reliability } \\
\hline & & Loads & $t$-Value & $\begin{array}{l}\text { Loading } \\
\text { Average }\end{array}$ & $\begin{array}{c}\text { Cronbach's } \\
\alpha\end{array}$ & $\begin{array}{l}\text { Composite } \\
\text { Reliability }\end{array}$ & AVE \\
\hline \multirow{3}{*}{$\begin{array}{l}\text { Social media gratifications } \\
\qquad\left(2^{\circ} \text { order }\right)\end{array}$} & EIS & 0.48 & 22.82 & \multirow{3}{*}{-} & \multirow{3}{*}{-} & \multirow{3}{*}{-} & \multirow{3}{*}{-} \\
\hline & ENT & 0.45 & 25.41 & & & & \\
\hline & $\mathrm{SOC}$ & 0.32 & 16.08 & & & & \\
\hline \multirow{3}{*}{ Leisure } & LEI1 & 0.94 & 97.22 & \multirow{3}{*}{0.95} & \multirow{3}{*}{0.95} & \multirow{3}{*}{0.97} & \multirow{3}{*}{0.91} \\
\hline & LEI2 & 0.95 & 149.36 & & & & \\
\hline & LEI3 & 0.96 & 162.77 & & & & \\
\hline \multirow{3}{*}{ Relaxation } & REL1 & 0.93 & 99.36 & \multirow{3}{*}{0.95} & \multirow{3}{*}{0.94} & \multirow{3}{*}{0.96} & \multirow{3}{*}{0.90} \\
\hline & REL2 & 0.96 & 158.18 & & & & \\
\hline & REL3 & 0.94 & 107.40 & & & & \\
\hline \multirow{4}{*}{ Learning/Discover } & LEA1 & 0.91 & 77.10 & \multirow{4}{*}{0.92} & \multirow{4}{*}{0.94} & \multirow{4}{*}{0.95} & \multirow{4}{*}{0.84} \\
\hline & LEA2 & 0.93 & 79.98 & & & & \\
\hline & LEA3 & 0.93 & 74.85 & & & & \\
\hline & LEA4 & 0.90 & 63.46 & & & & \\
\hline \multirow{3}{*}{ Social bonding } & BON1 & 0.92 & 85.07 & \multirow{3}{*}{0.91} & \multirow{3}{*}{0.90} & \multirow{3}{*}{0.94} & \multirow{3}{*}{0.83} \\
\hline & BON2 & 0.93 & 85.68 & & & & \\
\hline & BON3 & 0.89 & 61.50 & & & & \\
\hline
\end{tabular}

AVE $=$ average variance extracted.

The average variance extracted test [109] was used to evaluate discriminant validity: The test verifies that the square of the covariance of each pair of factors is less than the variance extracted from each of the factors. These conditions were met for all factors (see Table 5), confirming the discriminant validity of the measurement model.

Table 5. Discriminant validity of the research model, Fornell-Larcker criterion.

\begin{tabular}{ccccccccc}
\hline & GRAT & LEI & REL & LEA & BON & STICK & UGC & eWOM \\
\hline Gratifications & 0.69 & & & & & & & \\
Leisure & 0.59 & 0.95 & & & & & & \\
Relaxation & 0.53 & 0.72 & 0.95 & & & & & \\
Learning/discover & 0.54 & 0.70 & 0.69 & 0.92 & & & & \\
Social bonding & 0.58 & 0.61 & 0.64 & 0.67 & 0.91 & & & \\
Stickiness & 0.62 & 0.58 & 0.54 & 0.59 & 0.67 & 0.90 & & \\
$\quad$ UGC & 0.64 & 0.47 & 0.48 & 0.46 & 0.64 & 0.77 & 0.89 & \\
eWOM review adoption & 0.54 & 0.52 & 0.50 & 0.60 & 0.49 & 0.61 & 0.50 & 0.92 \\
\hline
\end{tabular}

Note: The diagonal represents the square root of the AVEs; the correlations between factors are represented below the diagonal. GRAT = gratification; $\mathrm{LEI}=$ leisure; $\mathrm{REL}=$ relaxation; $\mathrm{BON}=$ social bonding; STICK = stickiness.

The second criterion used was the Heterotrait-Monotrait (HTMT) ratio [111]; this criterion was established by Reference [112] to verify discriminant validity. This requires ratio values lower than 0.90. In Table 6 it can be seen that this criterion is, indeed, achieved, thus the measurement model has discriminant validity. 
Table 6. Discriminant validity of the research model. HTMT criterion.

\begin{tabular}{|c|c|c|c|c|c|c|c|c|}
\hline & GRAT & LEI & REL & LEA & BON & STICK & UGC & eWOM \\
\hline \multicolumn{9}{|l|}{ Gratifications } \\
\hline Leisure & 0.62 & & & & & & & \\
\hline Relaxation & 0.58 & 0.76 & & & & & & \\
\hline Learning/discover & 0.57 & 0.75 & 0.73 & & & & & \\
\hline Social bonding & 0.66 & 0.66 & 0.70 & 0.73 & & & & \\
\hline Stickiness & 0.63 & 0.71 & 0.59 & 0.65 & 0.75 & & & \\
\hline UGC & 0.65 & 0.63 & 0.52 & 0.57 & 0.71 & 0.68 & & \\
\hline eWOM review adoption & 0.57 & 0.55 & 0.53 & 0.64 & 0.53 & 0.67 & 0.53 & \\
\hline
\end{tabular}

\section{Results and Discussion}

The psychometric properties of the measurement model were evaluated and tested; the results are presented in terms of the structural relationships and their parameters, and the degree of fulfilment of the hypotheses. Table 7 shows that the coefficients of the relationships are statistically significant at $99 \%$ confidence level $(t>2.58)$, and that all the hypotheses of the theoretical model are supported.

Table 7. Structural equation modelling: causal relations analysis.

\begin{tabular}{|c|c|c|c|c|}
\hline Hypothesis & Structural Relationship & $\beta$ & $t$-Value & Result \\
\hline $\mathrm{H} 1$ & U\&G of social media $\rightarrow$ Stickiness & 0.29 & $5.93 * *$ & Accepted \\
\hline $\mathrm{H} 2$ & U\&G of social media $\rightarrow$ UGC & 0.25 & $5.48^{* *}$ & Accepted \\
\hline H3 & U\&G of social media $\rightarrow$ eWOM review adoption & 0.17 & $2.75^{* *}$ & Accepted \\
\hline $\mathrm{H} 4 \mathrm{a}$ & Leisure $\rightarrow$ Stickiness & 0.11 & 1.51 & Not accepted \\
\hline $\mathrm{H} 4 \mathrm{~b}$ & Relaxation $\rightarrow$ Stickiness & -0.01 & 0.11 & Not accepted \\
\hline $\mathrm{H} 4 \mathrm{c}$ & Learning/discover $\rightarrow$ Stickiness & 0.12 & $2.11 *$ & Accepted \\
\hline $\mathrm{H} 4 \mathrm{~d}$ & Social bonding $\rightarrow$ Stickiness & 0.36 & $6.21^{* *}$ & Accepted \\
\hline $\mathrm{H} 5 \mathrm{a}$ & Leisure $\rightarrow$ UGC & -0.08 & 1.48 & Not accepted \\
\hline $\mathrm{H} 5 \mathrm{~b}$ & Relaxation $\rightarrow$ UGC & 0.06 & 1.07 & Not accepted \\
\hline $\mathrm{H} 5 \mathrm{c}$ & Learning/discover $\rightarrow$ UGC & -0.13 & $2.46^{*}$ & Not accepted \\
\hline $\mathrm{H} 5 \mathrm{~d}$ & Social bonding $\rightarrow$ UGC & 0.22 & $4.45^{* *}$ & Accepted \\
\hline H6a & Leisure $\rightarrow$ eWOM review adoption & 0.02 & 0.21 & Not accepted \\
\hline $\mathrm{H} 6 \mathrm{~b}$ & Relaxation $\rightarrow$ eWOM review adoption & 0.05 & 0.69 & Not accepted \\
\hline H6c & Learning/discover $\rightarrow$ eWOM review adoption & 0.33 & $4.39 * *$ & Accepted \\
\hline H6d & Social bonding $\rightarrow$ eWOM review adoption & -0.11 & 1.69 & Not accepted \\
\hline $\mathrm{H} 7$ & Stickiness $\rightarrow$ UGC & 0.57 & $11.96^{* *}$ & Accepted \\
\hline $\mathrm{H} 8$ & Stickiness $\rightarrow$ eWOM review adoption & 0.34 & $5.15^{* *}$ & Accepted \\
\hline
\end{tabular}

The findings confirmed the direct positive relationship between gratifications provided by social media and the three behavioural variables analysed. In terms of the order of the intensity of the relationships, gratifications positively influence stickiness (H1 supported; $\beta=0.29^{* *}$ ), UGC (H2 supported; $\beta=0.25^{* *}$ ), and eWOM review adoption ( $\mathrm{H} 3$ supported; $\beta=0.17^{* *}$ ). This result extends previous findings $[39,41,45]$ and suggests that entertainment and expressive information sharing are important drivers of consumers' higher intentions to continue using social media, and information share. Consumers stick to social media to exchange travel information because they see them as (i) providing ways to have fun with entertaining content, (ii) as instruments for increasing their social

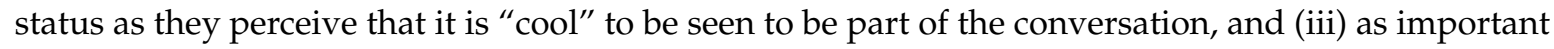
tools for exchanging knowledge and advice on travel destinations with friends, relatives, and other travellers. Social networks are fundamentally participatory; and sharing content on them is both a form of expression and a means of building relationships [113].

Travel motivations had a heterogeneous effect on consumer interactive behaviour. Leisure and relaxing travel motivations had no influence on any of the three variables analysed: stickiness $(\mathrm{H} 4 \mathrm{a}$ not supported; $\beta=0.11$; H4b not supported; $\beta=-0.01$ ), UGC (H5a not supported; $\beta=-0.08$; H5b not 
supported; $\beta=0.06$ ), and eWOM review adoption (H6a not supported; $\beta=0.02 ; \mathrm{H} 6 \mathrm{~b}$ not supported; $\beta=0.05)$. These results may arise because often relaxation- and leisure-driven consumers want to actually experience destinations, and are not interested in what, to them, are irrelevant social media interactions. As Reference [114] pointed out, for tourists to want to share experiences, those experiences have to be unique and memorable, and, the more senses an experience involves, the more effective and memorable it can be. Another explanation may be that the influence of intrinsic motivations (leisure and relaxation) on consumer interactive behaviour are affected by the type of social media used by the respondents to look for and/or exchange tourism information. This is in line with Reference [115]'s study, which de-emphasised the importance of the perceived enjoyment motivation for travel planning when using non-travel-specific social media for decision-making before a leisure trip.

Learning/discover had a positive effect on stickiness (H4c supported; $\beta=0.12^{*}$ ) and a positive, strong effect on eWOM review adoption (H6c supported; $\beta=0.33^{* *}$ ). These findings support previous research that argued that tourism motivations direct consumers towards the fulfilment of tourist needs in online travel communities (see Reference [10]), and influence consumers to follow advice to choose certain tourism destinations [81,82]. Motivations dispose consumers to decide to travel, and are subsequently interpretable by others as valid explanations to take travel-related decisions. However, the learning/discover motivation negatively impacts on UGC ( $\mathrm{H} 5 \mathrm{c}$ not supported; $\beta=-0.13^{* *}$ ). One explanation for this result may be that tourists will not post information when they perceive that the costs of knowledge sharing might exceed the benefits they will receive from the knowledge sharing [116].

The social-bonding motivation had a direct and positive effect on stickiness (H4d supported; $\beta=0.36^{* *}$ ) and UGC (H5d supported; $\left.\beta=0.22 * *\right)$. Social media generate social benefits related to not only the possibility of collecting information and reviews from peers before a trip, but also to sharing information during and after a trip and maintaining relationships within a social media community [115]. Social desirability compels travellers to stick to social media and recommend leisure tourism activities. This result extends the findings of previous research on the effects of social motivations on word-of-mouth in offline settings [76,77]. Social bonding did not influence eWOM review adoption (H6d not supported; $\beta=-0.11$ ). This result would seem, indeed, logical, given that social-bonding-related motivations are not obviously fulfilled by accepting recommendations from other travellers. Prospective travellers in search of tourism information driven by social motivations might be more interested in browsing and commenting on other travellers' social media content, such as photographs, videos, and comments (social-bonding motivation), rather than in the outcome of the information search process per se (visiting a destination).

If we focus on consumer interactive behaviour, stickiness influenced eWOM review adoption (H8 supported; $\beta=0.34^{* *}$ ) and continuance intention to create UGC (H7 supported; $\beta=0.57^{* *}$ ). These results are in line with recent research that argues that stickiness intention is a surrogate for behavioural loyalty to a website $[117,118]$. Therefore, stickiness can encourage travellers to post WOM [87] and generate a positive attitude towards advice obtained in online travel communities, which, in turn, increases the traveller's intention to adopt the eWOM [119]. Figure 2 shows the results of the model estimation. 


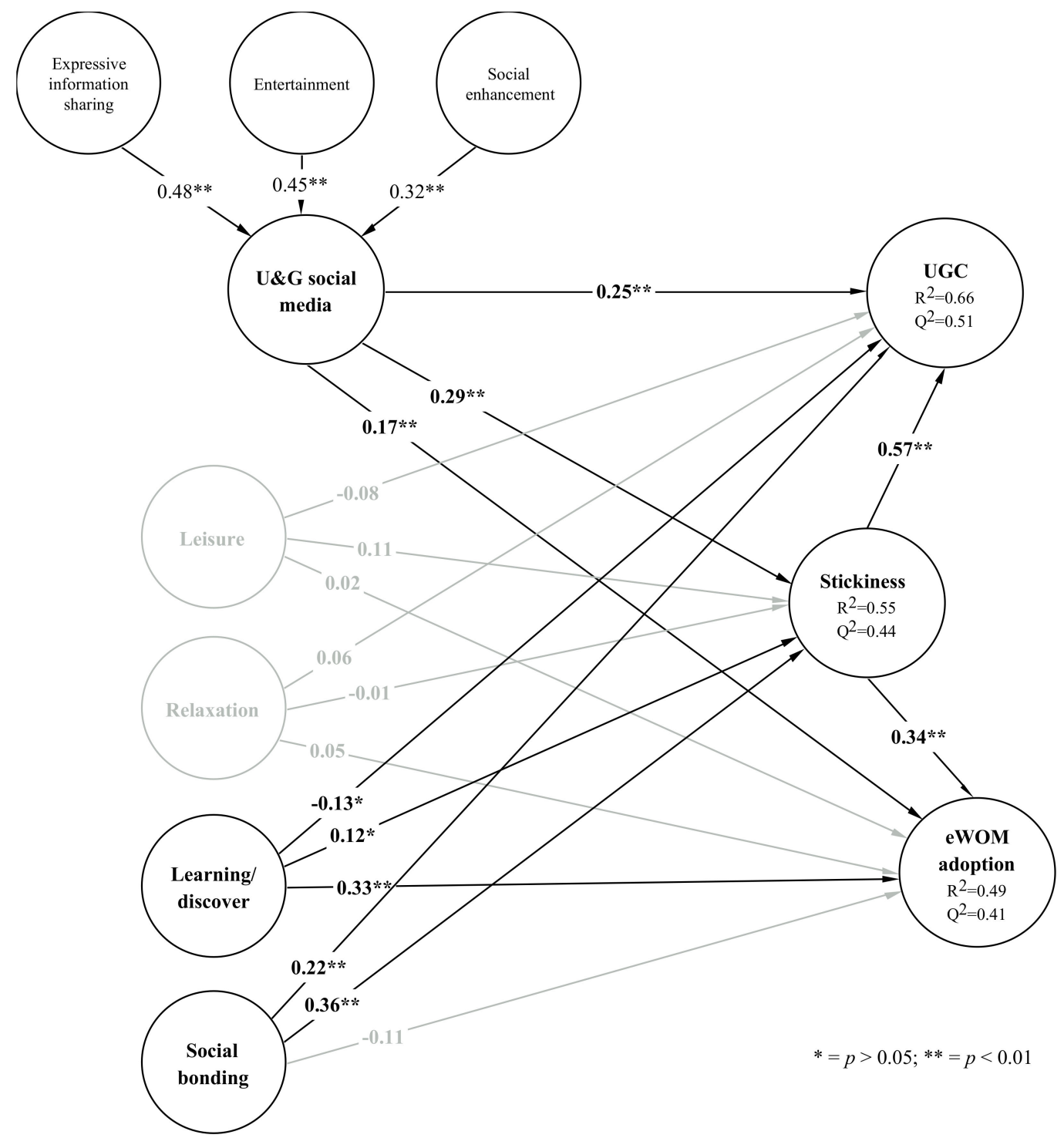

Figure 2. Estimated model.

\section{Conclusions}

This work contributes to the literature in several ways. First, by extending and adapting the concept of stickiness to the online travel communities' context, this study enriches the theoretical understanding of stickiness. Whereas previous studies have focused mainly on the antecedents of users' stickiness to websites, in this research, the impact of stickiness on consumer interactive behaviour is revealed. Overall, the model explains $66 \%$ of the variance of continuance intention to create user-generated content, $55 \%$ of the variance of stickiness, and $41 \%$ of the variance of eWOM review adoption.

Second, this study increases understanding of the theoretical mechanisms that underlie the development of travellers' stickiness. The UGT suggests that media use is motivated by needs and goals, while motivation theory proposes that consumer interactive behaviour is influenced by psychological states that direct consumers towards the fulfilment of tourism needs. Gratifications and motivations are found to have a significant impact on stickiness and sharing information behaviour, and the relationships of these factors are verified by UGT and motivation theory. Therefore, consumers will stick to a social media site to exchange travel information when their individual gratifications are met by the social media content. The results also indicated that push motivations have a 
heterogeneous influence on travellers' continuance usage intention, UGC, and intention to adopt the eWOM. The results verified that consumers' stickiness to online travel communities is a consequence of psychological drivers (i.e., learning/discover, social-bonding travel motivations, and the gratifications provided by social media). Most studies into stickiness have focused on demonstrating the influence of customer satisfaction, relationship commitment, and trust, in predicting consumers' stickiness in the contexts of B2C and B2B $[117,118]$. The present study innovatively adopts a new perspective by jointly examining two internal factors, travel motivations and gratifications, in an investigation into consumers' stickiness in the online travel communities' context. Our research findings provide insights into the adoption of psychological perspectives to effectively identify and investigate the key success factors that tourism companies must take into account in their social media operations. This study highlights the importance of gratifications provided by social media and consumer travel motivations because they have a direct, significant influence on social media stickiness, an essential variable for guaranteeing online travel community success. The gratifications obtained through social media condition the consumer's attachment to an online travel community, which can be reflected in his/her desire to transmit information to other consumers and in his/her intention to adopt the eWOM provided in social media. This research has analysed the functions of an online travel community from the consumer perspective and examined the gratifications provided by tourism-related information on social media to their readers.

The gratifications stemming from social-media use reinforce consumer interactive behaviour, which must be taken into account when designing online travel platforms. We can conclude that users stick to social media to share travel experiences with their friends/relatives/acquaintances, to amuse themselves and, to a lesser extent, to achieve social enhancement. Given the importance of information sharing gratification, online travel communities and tourism companies should include elements, such as frequently asked questions, blogs, virtual communities (spaces where a specific topic is discussed in connection with what the website offers), and discussion forums (general and specific), so that, by monitoring them, the companies can gather information on the participants and, thus, improve their services, and even the website itself. The impact of learning/discover and social bonding on stickiness to social media highlights the need for destination management organisations to take these travel motivations into account. The learning/discover travel motivation can be reinforced by the consumer's anticipation of the travel-related experiences. This sensation can be achieved by including attractive contents with audio-visual elements, such as videos, pictures, or music. Data might be provided on nearby tourist resources, such as museums; unique buildings of civil, military, or religious natures; and natural features, such as landscapes, cliffs, waterfalls, etc. Virtual reality tools can also give tourists alternative ways of learning, thus creating unique experiences. The feeling of belonging (social bonding) to the destination being visited plays an important role in stickiness and in the cultivation of intention to continue to create travel-related UGC. As Reference [120] found out in the context of heritage sites, in order to achieve customer loyalty unique experiences, novelty and the opportunity to explore tourist sites must be promoted. Photographs of, and information about, the destination might depict local traditions, festivities, etc. Destination Marketing Organizations (DMOs) should set up events that allow potential tourists to meet local people/connect with their culture (for example, in Malaysian jungle trips, tourists might be taken to see the indigenous jungle people making handicrafts with natural, sustainable materials).

A limitation of this study is that it uses a single data-collection source, so it may suffer from common method bias [121]. This phenomenon could be controlled in the future by multimethod studies, for example, by combining measurement instruments based on neuroscientific methods, such as eye-tracking. Social media are based on different forms of technology, and consumer behaviour can vary in relation to the channel used. Consequently, another future research line might apply the model to a sample of mobile social media users, to compare results. In addition, further research might explore moderator variables that differentiate user engagement (active users/posters versus passive users/lurkers). It seems increasingly important to explore the behaviour of "the silent majority" 
of holidaymakers, the lurkers that use social media to make their travel choices but do not share their experiences [122,123]. This study focuses only on the most important factors of individual gratifications; other related constructs that may affect online consumer behaviour should also be examined. It would, thus, be interesting for further research to extend the present model to investigate the relationships among gratifications, knowledge-sharing intention, and collective stickiness intention. Another future research line would be to analyse the moderating effects of social media type used (travel-specific or non-travel-specific) on consumer interactive behaviour. Recent research [76,83,84] has revealed that, although motivations may be sufficient antecedents of behavioural intentions in tourism, perceived risks can diminish the effects of motivations in shaping the behavioural intentions of travellers. Therefore, as a future research line, we propose to extend our conceptual model to include the effects of perceived risks on consumer interactive behaviour.

Author Contributions: Conceptualisation, C.R. and B.H.; methodology, L.C. and C.R.; software, R.C.; formal analysis, R.C. and L.C.; writing-original draft, L.C.; supervision, C.R.; funding acquisition, C.R. All authors have read and agreed to the published version of the manuscript.

Funding: This research was partially funded by Spanish Ministry of Science and Innovation, grant number PID2019-111195RB-I00.

Conflicts of Interest: The authors declare no conflict of interest.

\section{References}

1. Narangajavana Kaosiri, Y.; Callarisa Fiol, L.J.; Moliner Tena, M.A.; Rodriguez Artola, R.; Moliner Tena, M.A.; Sanchez Garcia, J. User-Generated Content Sources in Social Media: A New Approach to Explore Tourist Satisfaction. J. Travel Res. 2017, 58, 253-265. [CrossRef]

2. Kim, M.; Kim, J. The Influence of Authenticity of Online Reviews on Trust Formation among Travelers. J. Travel Res. 2019, 59, 763-776. [CrossRef]

3. Bigné, E.; Ruiz, C.; Curras-Perez, R. Destination Appeal Through Digitalized Comments. J. Bus. Res. 2019, 101, 447-453. [CrossRef]

4. Chung, N.; Nam, K.; Koo, C. Examining Information Sharing in Social Networking Communities: Applying Theories of Social Capital and Attachment. Telemat. Inform. 2016, 33, 77-91. [CrossRef]

5. Lee, J. Social Capital Expectation and Usage of Social Media: The Moderating Role of Social Capital Susceptibility. Behav. Inf. Technol. 2017, 36, 1067-1080. [CrossRef]

6. Caber, M.; Albayrak, T. Push or pull? Identifying Rock Climbing Tourists' Motivations. Tour. Manag. 2016, 55, 74-84. [CrossRef]

7. Mak, A.H.; Wong, K.K.F.; Chang, R.C.Y. Health or Self-Indulgence? the Motivations and Characteristics of Spa-Goers. Int. J. Tour. Res. 2009, 11, 185-199. [CrossRef]

8. Crompton, J.L.; McKay, S.L. Motives of Visitors Attending Festival Events. Ann. Tour. Res. 1997, $24,425-439$. [CrossRef]

9. Andriotis, K.; Agiomirgianakis, G. Cruise Visitors' Experience in a Mediterranean Port of Call. Int. J. Tour. Res. 2010, 12, 390-404. [CrossRef]

10. Hsu, C.-Y.; Lee, W.-H.; Chen, W.-Y. How to Catch Their Attention? Taiwanese Flashpackers Inferring Their Travel Motivation from Personal Development and Travel Experience. Asia Pac. J. Tour. Res. 2016, 22, 117-130. [CrossRef]

11. Jones, R.V. Motivations to Cruise: An Itinerary and Cruise Experience Study. J. Hosp. Tour. Manag. 2011, 18, 30-40. [CrossRef]

12. Anderson, J.A.; Meyer, T.P. Functionalism and the Mass Media. J. Broadcast. Electron. Media 1975, 19, 11-22. [CrossRef]

13. Krause, A.E.; North, A.C.; Heritage, B. The Uses and Gratifications of Using Facebook Music Listening Applications. Comput. Hum. Behav. 2014, 39, 71-77. [CrossRef]

14. Smock, A.D.; Ellison, N.B.; Lampe, C.; Wohn, D.Y. Facebook as a Toolkit: A Uses and Gratification Approach to Unbundling Feature Use. Comput. Hum. Behav. 2011, 27, 2322-2329. [CrossRef]

15. Malik, A.; Dhir, A.; Nieminen, M. Uses and Gratifications of digital photo sharing on Facebook. Telemat. Inform. 2016, 33, 129-138. [CrossRef] 
16. Koh, J.; Kim, Y.-G. Knowledge Sharing in Virtual Communities: An E-Business Perspective. Expert Syst. Appl. 2004, 26, 155-166. [CrossRef]

17. Bhatnagar, A.; Ghose, S. An Analysis of Frequency and Duration of Search on the Internet. J. Bus. 2004, 77, 311-330. [CrossRef]

18. Banerjee, S.; Chua, A.Y. In Search of Patterns Among Travellers' Hotel Ratings in TripAdvisor. Tour. Manag. 2016, 53, 125-131. [CrossRef]

19. Casaló, L.V.; Flavián, C.; Guinalíu, M. Understanding the Intention to Follow the Advice Obtained in an Online Travel Community. Comput. Hum. Behav. 2011, 27, 622-633. [CrossRef]

20. Ruiz-Mafe, C.; Bigné-Alcañiz, E.; Currás-Pérez, R. The Effect of Emotions, eWOM Quality and Online Review Sequence on Consumer Intention to Follow Advice Obtained from Digital Services. J. Serv. Manag. 2020, 31, 465-487. [CrossRef]

21. Katz, E.; Haas, H.; Gurevitch, M. On the Use of the Mass Media for Important Things. Am. Sociol. Rev. 1973, 38, 164. [CrossRef]

22. Dhir, A.; Khalil, A.; Lonka, K.; Tsai, C.-C. Do Educational Affordances and Gratifications Drive Intensive Facebook Use Among Adolescents? Comput. Hum. Behav. 2017, 68, 40-50. [CrossRef]

23. Katz, E. Mass Communication Research and the Study of Popular Culture: An Editorial Note on a Possible Future for This Research. Stud. Public Commun. 1959, 2, 1-6.

24. Swanson, D.L. Political Communication Research and the Uses and Gratifications Model a Critique. Commun. Res. 1979, 6, 37-53. [CrossRef]

25. Becker, L.B. Measurement of Gratifications. Commun. Res. 1979, 6, 54-73. [CrossRef]

26. O'Donohoe, S. Advertising Uses and Gratifications. Eur. J. Mark. 1994, 28, 52-75. [CrossRef]

27. Ruggiero, T.E. Uses and Gratifications Theory in the 21st Century. Mass Commun. Soc. 2000, 3, 3-37. [CrossRef]

28. Phua, J.; Jin, S.V.; Kim, J. Gratifications of Using Facebook, Twitter, Instagram, or Snapchat to Follow Brands: The Moderating Effect of Social Comparison, Trust, Tie Strength, and Network Homophily on Brand Identification, Brand Engagement, Brand Commitment, and Membership Intention. Telemat. Inform. 2017, 34, 412-424. [CrossRef]

29. Korgaonkar, P.K.; Wolin, L.D. A Multivariate Analysis of Web Usage. J. Advert. Res. 1999, $39,53$.

30. Dolan, R.; Conduit, J.; Fahy, J.; Goodman, S. Social Media Engagement Behaviour: A Uses and Gratifications Perspective. J. Strat. Mark. 2015, 24, 261-277. [CrossRef]

31. Yen, W.-C.; Lin, H.-H.; Wang, Y.-S.; Shih, Y.-W.; Cheng, K.-H. Factors Affecting Users' Continuance Intention of Mobile Social Network Service. Serv. Ind. J. 2018, 39, 983-1003. [CrossRef]

32. Ha, Y.W.; Kim, J.; Libaque-Saenz, C.F.; Chang, Y.; Park, M.-C. Use and Gratifications of Mobile SNSs: Facebook and KakaoTalk in Korea. Telemat. Inform. 2015, 32, 425-438. [CrossRef]

33. Kim, M.J.; Lee, C.-K.; Contractor, N.S. Seniors' Usage of Mobile Social Network Sites: Applying Theories of Innovation Diffusion and Uses and Gratifications. Comput. Hum. Behav. 2019, 90, 60-73. [CrossRef]

34. Choi, E.-K.; Fowler, D.; Goh, B.; Yuan, J.J. Social Media Marketing: Applying the Uses and Gratifications Theory in the Hotel Industry. J. Hosp. Mark. Manag. 2015, 25, 771-796. [CrossRef]

35. Hur, K.; Kim, T.T.; Karatepe, O.M.; Lee, G. An Exploration of the Factors Influencing Social Media Continuance Usage and Information Sharing Intentions Among Korean Travellers. Tour. Manag. 2017, 63, 170-178. [CrossRef]

36. Plume, C.J.; Slade, E.L. Sharing of Sponsored Advertisements on Social Media: A Uses and Gratifications Perspective. Inf. Syst. Front. 2018, 20, 471-483. [CrossRef]

37. Ho, C.-T.B.; Gebsombut, N. Communication Factors Affecting Tourist Adoption of Social Network Sites. Sustainability 2019, 11, 4198. [CrossRef]

38. Bu, Y.; Parkinson, J.; Thaichon, P. Digital Content Marketing as a Catalyst for e-WOM in Food Tourism. Australas. Mark. J. (AMJ) 2020. [CrossRef]

39. Eighmey, J.; Mccord, L. Adding Value in the Information Age: Uses and Gratifications of Sites on the World Wide Web. J. Bus. Res. 1998, 41, 187-194. [CrossRef]

40. Curras-Perez, R.; Ruiz-Mafe, C.; Sanz-Blas, S. Determinants of User Behaviour and Recommendation in Social Networks. Ind. Manag. Data Syst. 2014, 114, 1477-1498. [CrossRef]

41. Muntinga, D.G.; Moorman, M.; Smit, E.G. Introducing COBRAs. Int. J. Advert. 2011, 30, 13-46. [CrossRef] 
42. Katz, J.E.; Sugiyama, S. Mobile Phones as Fashion Statements: The Co-creation of Mobile Communication's Public Meaning. In Serious Games; Springer Science and Business Media LLC: London, UK, 2005; pp. 63-81.

43. Nysveen, H.; Pedersen, P.E.; Thorbjørnsen, H. Intentions to Use Mobile Services: Antecedents and Cross-Service Comparisons. J. Acad. Mark. Sci. 2005, 33, 330-346. [CrossRef]

44. Smedlund, A.; Faghankhani, H. Platform Orchestration for Efficiency, Development, and Innovation. In Proceedings of the 2015 48th Hawaii International Conference on System Sciences, Kauai, HI, USA, 5-8 January 2015; pp. 1380-1388.

45. Quan-Haase, A.; Young, A.L. Uses and Gratifications of Social Media: A Comparison of Facebook and Instant Messaging. Bull. Sci. Technol. Soc. 2010, 30, 350-361. [CrossRef]

46. Holton, A.E.; Baek, K.; Coddington, M.; Yaschur, C. Seeking and Sharing: Motivations for Linking on Twitter. Commun. Res. Rep. 2014, 31, 33-40. [CrossRef]

47. Hanson, G.; Haridakis, P. YouTube Users Watching and Sharing the News: A Uses and Gratifications Approach. J. Electron. Publ. 2008, 11. [CrossRef]

48. Taylor, D.G.; Strutton, D.; Thompson, K. Self-Enhancement as a Motivation for Sharing Online Advertising. J. Interact. Advert. 2012, 12, 13-28. [CrossRef]

49. Alhabash, S.; Chiang, Y.-H.; Huang, K. MAM \& U\&G in Taiwan: Differences in the Uses and Gratifications of Facebook as a Function of Motivational Reactivity. Comput. Hum. Behav. 2014, 35, 423-430. [CrossRef]

50. Baek, K.; Holton, A.; Harp, D.; Yaschur, C. The Links That Bind: Uncovering Novel Motivations for Linking on Facebook. Comput. Hum. Behav. 2011, 27, 2243-2248. [CrossRef]

51. Quinn, K. Contextual Social Capital: Linking the Contexts of Social Media Use to Its Outcomes. Inf. Commun. Soc. 2016, 19, 582-600. [CrossRef]

52. Bock, G.-W.; Zmud, R.W.; Kim, Y.-G.; Lee, J.-N. Behavioral Intention Formation in Knowledge Sharing: Examining the Roles of Extrinsic Motivators, Social-Psychological Forces, and Organizational Climate. MIS Q. 2005, 29, 87. [CrossRef]

53. Kankanhalli, A.; Tan, B.C.Y.; Wei, K.-K. Contributing Knowledge to Electronic Knowledge Repositories: An Empirical Investigation. MIS Q. 2005, 29, 113. [CrossRef]

54. Söderlund, M.; Rosengren, S. Receiving Word-of-Mouth From the Service Customer: An Emotion-Based Effectiveness Assessment. J. Retail. Consum. Serv. 2007, 14, 123-136. [CrossRef]

55. Bigné, E.; Ruiz, C.; Andreu, L.; Hernández-Ortega, B.; Ruiz, C. The Role of Social Motivations, Ability, and Opportunity in Online Know-How Exchanges: Evidence from the Airline Services Industry. Serv. Bus. 2013, 9, 209-232. [CrossRef]

56. Hew, J.-J.; Tan, G.W.-H.; Lin, B.; Ooi, K.-B. Generating Travel-Related Contents through Mobile Social Tourism: Does Privacy Paradox Persist? Telemat. Inform. 2017, 34, 914-935. [CrossRef]

57. Goh, K.-Y.; Heng, C.-S.; Lin, Z. Social Media Brand Community and Consumer Behavior: Quantifying the Relative Impact of User-and Marketer-Generated Content. Inf. Syst. Res. 2013, 24, 88-107. [CrossRef]

58. Luo, Q.; Zhong, D. Using Social Network Analysis to Explain Communication Characteristics of Travel-Related Electronic Word-of-Mouth on Social Networking Sites. Tour. Manag. 2015, 46, 274-282. [CrossRef]

59. Dann, G.M. Anomie, Ego-enhancement and Tourism. Ann. Tour. Res. 1977, 4, 184-194. [CrossRef]

60. Uysal, M.; Hagan, L.A.R. Motivation of Pleasure Travel and Tourism. Encycl. Hosp. Tour. 1993, $21,798-810$.

61. Fodness, D. Measuring Tourist Motivation. Ann. Tour. Res. 1994, 21, 555-581. [CrossRef]

62. Uysal, M.; Jurowski, C. Testing the Push and Pull Factors. Ann. Tour. Res. 1994, 21, 844-846. [CrossRef]

63. Iso-Ahola, S.E. Toward a Social Psychological Theory of Tourism Motivation: A Rejoinder. Ann. Tour. Res. 1982, 9, 256-262. [CrossRef]

64. Chua, B.-L.; Lee, S.; Han, H. Consequences of Cruise Line Involvement: A Comparison of First-Time and Repeat Passengers. Int. J. Contemp. Hosp. Manag. 2017, 29, 1658-1683. [CrossRef]

65. Han, H.; Hyun, S.S. Role of Motivations for Luxury Cruise Traveling, Satisfaction, and Involvement in Building Traveler Loyalty. Int. J. Hosp. Manag. 2018, 70, 75-84. [CrossRef]

66. Crompton, J.L. An Assessment of the Image of Mexico as a Vacation Destination and the Influence of Geographical Location Upon That Image. J. Travel Res. 1979, 17, 18-23. [CrossRef]

67. Duman, T.; Mattila, A.S. The Role of Affective Factors on Perceived Cruise Vacation Value. Tour. Manag. 2005, 26, 311-323. [CrossRef]

68. Hung, K.; Petrick, J.F. Why Do You Cruise? Exploring the Motivations for Taking Cruise Holidays, and the Construction of a Cruising Motivation Scale. Tour. Manag. 2011, 32, 386-393. [CrossRef] 
69. Kovačić, S.; Kennell, J.; Vujičić, M.D.; Jovanovic, T. Urban Tourist Motivations: Why Visit Ljubljana? Int. J. Tour. Cities 2017, 3, 382-398. [CrossRef]

70. Lee, S.; Chua, B.-L.; Han, H. Role of Service Encounter and Physical Environment Performances, Novelty, Satisfaction, and Affective Commitment in Generating Cruise Passenger Loyalty. Asia Pac. J. Tour. Res. 2016, 22, 1-16. [CrossRef]

71. Aldao, C.; Mihalic, T.A. New Frontiers in Travel Motivation and Social Media: The Case of Longyearbyen, the High Arctic. Sustainabiloity 2020, 12, 5905. [CrossRef]

72. Katsikari, C.; Hatzithomas, L.; Fotiadis, T.; Folinas, D. Push and Pull Travel Motivation: Segmentation of the Greek Market for Social Media Marketing in Tourism. Sustainability 2020, 12, 4770. [CrossRef]

73. Narangajavana, Y.; Fiol, L.J.C.; Tena, M.Á.M.; Artola, R.M.R.; García, J.S. The Influence of Social Media in Creating Expectations. an Empirical Study for a Tourist Destination. Ann. Tour. Res. 2017, 65, 60-70. [CrossRef]

74. Loureiro, S.M.C.; Stylos, N.; Bellou, V. Destination Atmospheric Cues as Key Influencers of Tourists' Word-of-Mouth Communication: Tourist Visitation at Two Mediterranean Capital Cities. Tour. Recreat. Res. 2020, 1-24. [CrossRef]

75. Yang, F.X. Effects of Restaurant Satisfaction and Knowledge Sharing Motivation on eWOM Intentions: The Moderating Role of Technology Acceptance Factors. J. Hosp. Tour. Res. 2017, 41, 93-127. [CrossRef]

76. Mehran, J.; Olya, H.; Han, H.; Kapuscinski, G. Determinants of Canal Boat Tour Participant Behaviours: An Explanatory Mixed-Method Approach. J. Travel Tour. Mark. 2020, 37, 112-127. [CrossRef]

77. Antón, C.; Camarero, C.; Laguna-García, M. Towards a New Approach of Destination Loyalty Drivers: Satisfaction, Visit Intensity and Tourist Motivations. Curr. Issues Tour. 2014, 20, 238-260. [CrossRef]

78. Pan, S.; Lee, J.; Tsai, H. Travel Photos: Motivations, Image Dimensions, and Affective Qualities of Places. Tour. Manag. 2014, 40,59-69. [CrossRef]

79. Kang, M.; Schuett, M.A. Determinants of Sharing Travel Experiences in Social Media. J. Travel Tour. Mark. 2013, 30, 93-107. [CrossRef]

80. Hanqin, Z.Q.; Lam, T. An Analysis of Mainland Chinese Visitors' Motivations to Visit Hong Kong. Tour. Manag. 1999, 20, 587-594. [CrossRef]

81. Kim, H.; Lee, S.; Uysal, M.; Kim, J.; Ahn, K. Nature-Based Tourism: Motivation and Subjective Well-Being. J. Travel Tour. Mark. 2015, 32, S76-S96. [CrossRef]

82. Kim, K.; Jogaratnam, G.; Noh, J. Travel Decisions of Students at a Us University: Segmenting the International Market. J. Vacat. Mark. 2006, 12, 345-357. [CrossRef]

83. Olya, H.G.T.; Han, H. Antecedents of Space Traveler Behavioral Intention. J. Travel Res. 2019, 59, 528-544. [CrossRef]

84. Fuchs, G.; Reichel, A. An Exploratory Inquiry into Destination Risk Perceptions and Risk Reduction Strategies of First Time vs. Repeat Visitors to a Highly Volatile Destination. Tour. Manag. 2011, 32, 266-276. [CrossRef]

85. Teng, C.-I. Customization, Immersion Satisfaction, and Online Gamer Loyalty. Comput. Hum. Behav. 2010, 26, 1547-1554. [CrossRef]

86. Oliver, L. Whence Consumer Loyalty. J. Mark. 1999, 63, 33-44. [CrossRef]

87. Zhang, M.; Guo, L.; Hu, M.; Liu, W. Influence of Customer Engagement with Company Social Networks on Stickiness: Mediating Effect of Customer Value Creation. Int. J. Inf. Manag. 2017, 37, 229-240. [CrossRef]

88. Schuckert, M.; Liu, X.; Law, R. A Segmentation of Online Reviews by Language Groups: How English and Non-English Speakers Rate Hotels Differently. Int. J. Hosp. Manag. 2015, 48, 143-149. [CrossRef]

89. Yen, C. How to Unite the Power of the Masses? Exploring Collective Stickiness Intention in Social Network Sites From the Perspective of Knowledge Sharing. Behav. Inf. Technol. 2015, 35, 118-133. [CrossRef]

90. Molina-Azorin, J.F. Mixed Methods Research: An Opportunity to Improve Our Studies and Our Research Skills. Eur. J. Manag. Bus. Econ. 2016, 25, 37-38. [CrossRef]

91. Trochim, W.M. An Introduction to Concept Mapping for Planning and Evaluation. Eval. Program Plan. 1989, 12, 1-16. [CrossRef]

92. Alvarado-Herrera, A.; Bigné, E.; Aldás-Manzano, J.; Curras-Perez, R. A Scale for Measuring Consumer Perceptions of Corporate Social Responsibility Following the Sustainable Development Paradigm. J. Bus. Ethics 2015, 140, 243-262. [CrossRef]

93. Hootsuite. The Global State of Digital in October 2019. Available online: https://wearesocial.com/us/blog/ 2019/10/the-global-state-of-digital-in-october-2019 (accessed on 13 December 2019). 
94. Lohmöller, J.-B. Latent Variable Path Modeling with Partial Least Squares; Physica: Heidelberg, Germany, 1989.

95. Guide, V.D.R.; Ketokivi, M. Notes from the Editors: Redefining Some Methodological Criteria for the Journal. J. Oper. Manag. 2015, 37, 5-8. [CrossRef]

96. Rönkkö, M.; McIntosh, C.N.; Antonakis, J.; Edwards, J.R. Partial Least Squares Path Modeling: Time for Some Serious Second Thoughts. J. Oper. Manag. 2016, 47, 9-27. [CrossRef]

97. Henseler, J.; Hubona, G.; Ray, P.A. Using PLS Path Modeling in New Technology Research: Updated Guidelines. Ind. Manag. Data Syst. 2016, 116, 2-20. [CrossRef]

98. Hair, J.F.; Howard, M.C.; Nitzl, C. Assessing Measurement Model Quality in PLS-SEM Using Confirmatory Composite Analysis. J. Bus. Res. 2020, 109, 101-110. [CrossRef]

99. Chin, W.W.; Newsted, P.R. Structural Equation Modeling Analysis with Small Samples Using Partial Least Squares. Stat. Strateg. Small Sample Res. 1999, 1, 307-341.

100. Chin, W.W.; Marcolin, B.L.; Newsted, P.R. A Partial Least Squares Latent Variable Modeling Approach for Measuring Interaction Effects: Results from a Monte Carlo Simulation Study and an Electronic-Mail Emotion/Adoption Study. Inf. Syst. Res. 2003, 14, 189-217. [CrossRef]

101. Fornell, C.; Cha, F.J. Partial Least Squares. Adv. Methods Mark. Res. 1994, 407, 52-78.

102. Ringle, C.M.; Wende, S.; Becker, J.-M. SmartPLS 3; SmartPLS GmbH: Boenningstedt, Germany, 2015; Available online: http://www.smartpls.com (accessed on 12 January 2019).

103. Papacharissi, Z.; Mendelson, A. 12 Toward a New(er) Sociability: Uses, Gratifications and Social Capital on Facebook. In Media Perspectives for the 21st Century; Taylor \& Francis Group: Abingdon-on-Thames, UK, 2011; pp. 212-230.

104. Hollenbaugh, E.E. Motives for Maintaining Personal Journal Blogs. Cyberpsychol. Behav. Soc. Netw. 2011, 14, 13-20. [CrossRef]

105. Lin, J.C.-C. Online Stickiness: Its Antecedents and Effect on Purchasing Intention. Behav. Inf. Technol. 2007, 26, 507-516. [CrossRef]

106. Oum, S.; Han, D. An Empirical Study of the Determinants of the Intention to Participate in User-Created Contents (UCC) Services. Expert Syst. Appl. 2011, 38, 15110-15121. [CrossRef]

107. Cheung, M.Y.; Luo, C.; Sia, C.L.; Chen, H. Credibility of Electronic Word-of-Mouth: Informational and Normative Determinants of On-line Consumer Recommendations. Int. J. Electron. Commer. 2009, 13, 9-38. [CrossRef]

108. Nunnally, J.C.; Bernstein, I.H. Psychometric Theory; McGraw-Hill: New York, NY, USA, 1994.

109. Fornell, C.; Larcker, D.F. Evaluating Structural Equation Models with Unobservable Variables and Measurement Error. J. Mark. Res. 1981, 18, 39-50. [CrossRef]

110. Bagozzi, R.P.; Yi, Y. On the Evaluation of Structural Equation Models. J. Acad. Mark. Sci. 1988, 16, 74-94. [CrossRef]

111. Henseler, J.; Dijkstra, T.K.; Sarstedt, M.; Ringle, C.M.; Diamantopoulos, A.; Straub, D.W.; Ketchen, J.D.J.; Hair, J.F.; Hult, G.T.M.; Calantone, R.J. Common Beliefs and Reality About PLS. Organ. Res. Methods 2014, 17, 182-209. [CrossRef]

112. Gold, A.H.; Malhotra, A.; Segars, A.H. Knowledge Management: An Organizational Capabilities Perspective. J. Manag. Inf. Syst. 2001, 18, 185-214. [CrossRef]

113. Van House, N.; Davis, M.; Ames, M.; Finn, M.; Viswanathan, V. The Uses of Personal Networked Digital Imaging. In Proceedings of the Communication CHI '05 Extended Abstracts on Human Factors in Computing Systems, Portland, OR, USA, 2-7 April 2005; pp. 1853-1856. [CrossRef]

114. Hung, W.-L.; Lee, Y.-J.; Huang, P.-H. Creative Experiences, Memorability and Revisit Intention in Creative Tourism. Curr. Issues Tour. 2014, 19, 763-770. [CrossRef]

115. Mariani, M.; Styven, M.E.; Ayeh, J.K. Using Facebook for Travel Decision-Making: An International Study of Antecedents. Int. J. Contemp. Hosp. Manag. 2019, 31, 1021-1044. [CrossRef]

116. Hsu, M.-H.; Ju, T.L.; Yen, C.-H.; Chang, C.-M. Knowledge Sharing Behavior in Virtual Communities: The Relationship Between Trust, Self-Efficacy, and Outcome Expectations. Int. J. Hum. Comput. Stud. 2007, 65, 153-169. [CrossRef]

117. Wang, W.-T.; Wang, Y.-S.; Liu, E.-R. The Stickiness Intention of Group-Buying Websites: The Integration of the Commitment-Trust Theory and E-Commerce Success Model. Inf. Manag. 2016, 53, 625-642. [CrossRef]

118. Hu, L.; Min, Q.; Han, S.; Liu, Z. Understanding Followers' Stickiness to Digital Influencers: The Effect of Psychological Responses. Int. J. Inf. Manag. 2020, 54, 102169. [CrossRef] 
119. Casaló, L.V.; Flavián, C.; Ibáñez-Sánchez, S. Antecedents of Consumer Intention to Follow and Recommend an Instagram Account. Online Inf. Rev. 2017, 41, 1046-1063. [CrossRef]

120. Olya, H.; Lee, C.-K.; Lee, Y.-K.; Reisinger, Y. What Are the Triggers of Asian Visitor Satisfaction and Loyalty in the Korean Heritage Site? J. Retail. Consum. Serv. 2019, 47, 195-205. [CrossRef]

121. Podsakoff, P.M.; MacKenzie, S.B.; Lee, J.Y.; Podsakoff, N.P. Common Method Biases in Behavioral Research: A Critical Review of the Literature and Recommended Remedies. J. Appl. Psychol. 2003, 88, 879. [CrossRef]

122. Bigne, E.; Andreu, L.; Pérez-Cabañero, C.; Ruiz, C. Brand Love Is All Around: Loyalty Behaviour, Active and Passive Social Media Users. Curr. Issues Tour. 2019, 23, 1613-1630. [CrossRef]

123. Oliveira, T.; Araujo, B.; Tam, C. Why Do People Share Their Travel Experiences on Social Media? Tour. Manag. 2020, 78, 104041. [CrossRef]

Publisher's Note: MDPI stays neutral with regard to jurisdictional claims in published maps and institutional affiliations.

(C) 2020 by the authors. Licensee MDPI, Basel, Switzerland. This article is an open access article distributed under the terms and conditions of the Creative Commons Attribution (CC BY) license (http://creativecommons.org/licenses/by/4.0/). 